\title{
Strain Partitioning Controlled by Oblique Ramp in Intracratonic Chains in Tunisia: Example of Gafsa Basin
}

\author{
Soulef Amamria ${ }^{1}$, Mohamed Sadok Bensalem ${ }^{2}$, Eric Mercier $^{3}$, Mohamed Ghanmi ${ }^{1}$, Fouad Zargouni ${ }^{1}$ \\ ${ }^{1}$ University of Sciences of Tunis, University of Tunis El Manar, Tunis, Tunisia \\ ${ }^{2}$ Faculty of Sciences of Gabes, University of Gabes, Erriadh City, Tunisia \\ ${ }^{3}$ Department of Sciences and Technique, University of Nantes, Nantes, France \\ Email: soulefamamria@gmail.com
}

Received December 13, 2012; revised January 11, 2013; accepted February 9, 2013

\begin{abstract}
The aim of this contribution is the interpretation of intracratonic chains in African plates, but it is important to verify some parameters such us the oblique convergence between Africa and Europa plates. Particularly in southern central of atlassic Tunisian belts, the slickenside examination of directional preexisting faults of N120 direction shows the coexistence of thrusting and strike-slip faults striation. In the limits of these faults principally in some tectonics lens we distinguish abnormal contacts with Triassic facies. The kinematic evolution of Gafsa basin resumed in the geometry of strike-slip faults connected in the thrusting system, this movement resulted from the oblique convergence on Ben Younes, Bou Ramli and Attig chains during compressive phases. This deformation style requires a shortening axis oblique to the NW-SE accidents (N120). The strain partitioning model verify the geometry of faults and equivalent evolution of folds and confirms the Triassic decollement level but without integrated of basement structures in the deformation. It permeated a passive transport of deformation observed in cover structure.
\end{abstract}

Keywords: Intracratonic Chains; Strain Partitioning; Convergence; Oblique Shortening

\section{Introduction}

The geological complexity of Africo-European convergence controlled the variability of deformation mode in the intracratonic chains of Tunisia. [1] demonstrate that the velocity of convergence of Africo-European plaques is between 3 and 8 millimeters for year in the longitude of Sicily.

According to [2], the obliquity convergence between African and European plate is compensated of 200 to 300 kilometers of African lithosphere under Ibero-European stroke. Consequently the Africo-European convergence immersed in the Magrebide chains and exactly in most important faults [1].

Many works focus on the study of the largest faults in North African craton proposes some model to interpret the deformation mode of structures in the limits of south atlassic front [3-7]. In this study the model of strain partitioning is the mechanism of genesis of major folds, this model is controlled by the properties of rocks, the tectonic inheritance and the role of preexistent faults. Therefore another parameter which is essential in the model of partitioning is the coefficient of friction along the fault [8-11], and the presence of decollement level can support the model of strain partitioning because it makes it possible to connect the thrusting and the strike slip faults. [12,13] shows that the faults meet starting from this decollement level.

The locality of Gafsa basin in the active tectonics context is responsible to genesis of folds in different direction limited by the major direction of faults (N120 to N140). The geometry of folds in Gafsa basin is controlled by the combination of thrust and strike-slip faults and the obliquity shortening axis to NW-SE major faults (Figure 1).

This object is studied by the example of Gafsa basin particularly the locality of J. Ben Younes, J. Attig, J. Bou Ramli, J. Es Stah and J. Orbat (Figure 2). It is an external zone affected by the oriental continuity of front south atlassic of NW-SE direction in this zone.

Many models are proposed to interpret the geometry of folds in the limits of southern atlassic front, but the most important problem is the implication of the basement in deformation. This study is focus on treatment of surface data with different parameters in order to correlate the kinematics of subsurface context.

\section{Tectonics Events}

The Tunisia is situated in the north east part of the African plate; this later is surrounded by $90 \%$ of Oceanic 


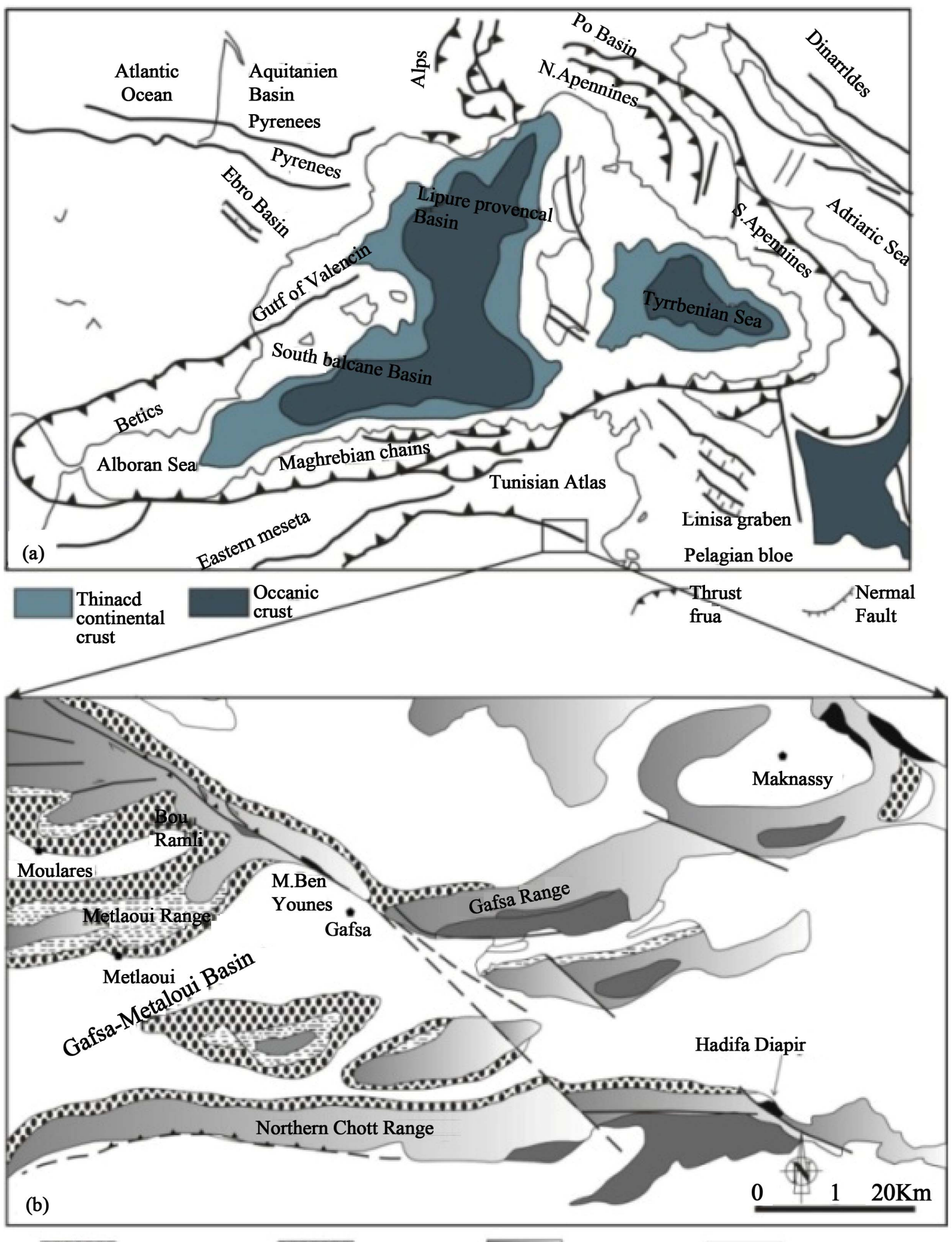

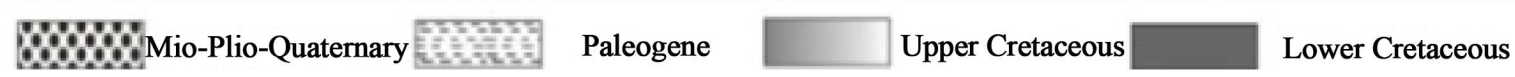

Figure 1. (a) Tectonic pattern of the western Mediterranean shows the major thrust front in the two part of alpine chains (European and African) [14]; (b) Location map of southern central Tunisia presented outcropped majority of cretaceous series affected by the major directional faults. 


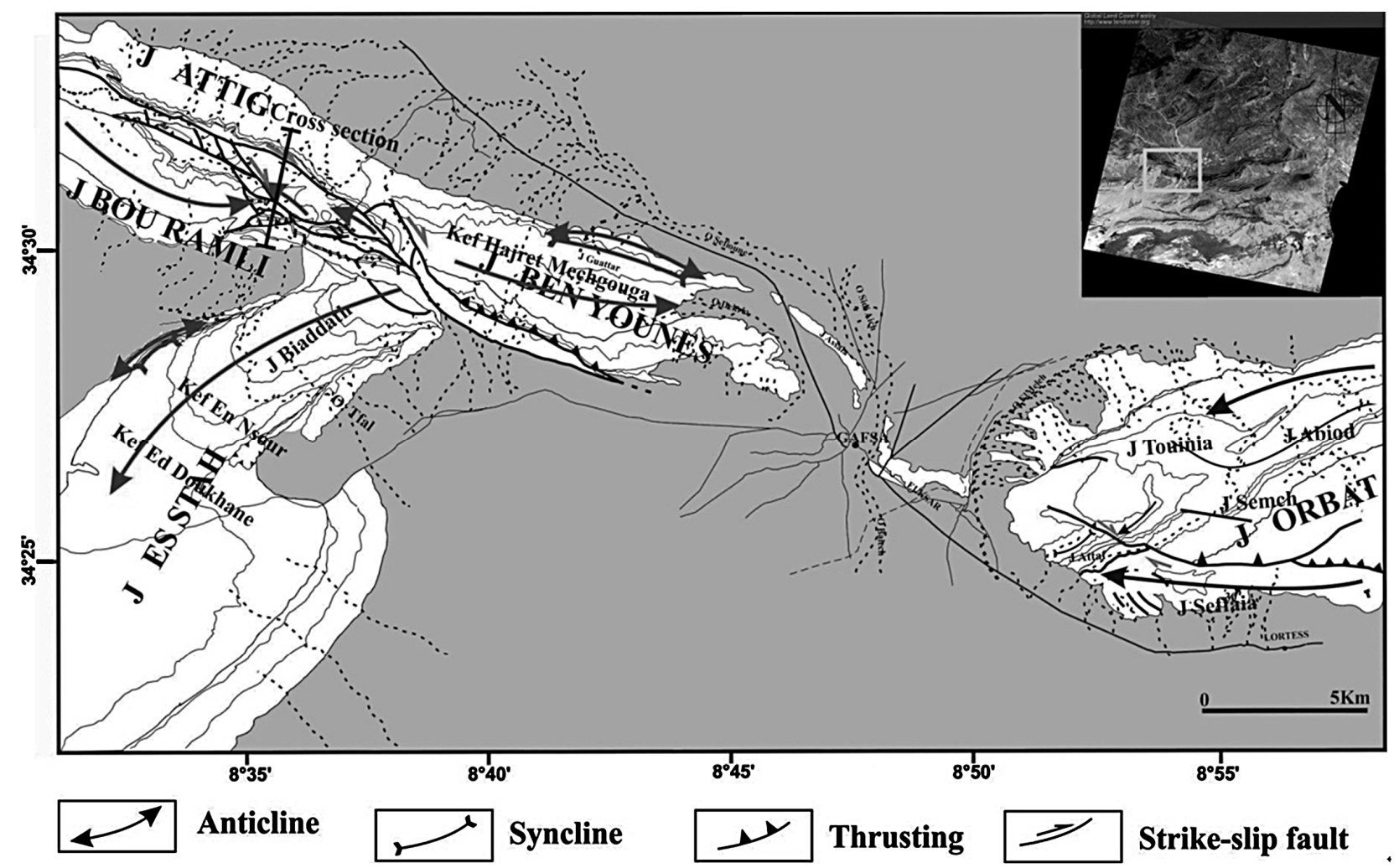

Figure 2. Map of localization of majors accidents which assign Gafsa basin of E-W to NW-SE.

dorsal that undergoes the most consequences of Cenozoic convergence of Afrique and European plaques [15]. Consequently the Tunisian area evokes many tectonics phases.

According to $[16,17]$, the Magrebide platform is affected by syntectonics filling of graben and half-graben during upper Trias and lower Lias. Through the middle Lias a carbonated platform established, finally a Cenomano-Turronian transgression covers the all system.

In the Atlassic domain Tunisian an extensive phase is related to the Tethys opening according to NW-SE and E-W fault activity expressed by depression of Jeffara bloc $[15,18]$ demonstrate that the Africo-European movement during middle Jurassic and lower Cretaceous corresponding to sinistral lateral displacement. During Cretaceous an extensive mechanism of NE-SW to ENEWSW trends is consequence of derives of African Plaque. This extension occurs in same time of drives of Apulian bloc that detached from African plaque during Crétaceous [19]. At the end of Cretaceous period the African and European plaques launch its convergence with slow velocity (less than 10 centimeters/year) [20]. The most important compressive phase is atlassic one of Tortonian age of NW-SE direction associated to Tethys closing and continues during post-villafranchian phase of N-S trends; these two phases are responsible to genesis of folds according to NE-SW and E-W direction. Some authors [21] prove the activity of Eocene compressive phase but aren't verified in studied sector.

The south atlassic front correspond to faults corridors that extends from Algerian territory to oriental limits of Tunisian front. The Gafsa basin is a part of this domain delimited by NW-SE faults that controlled the tectono-sedimentary evolution of chains from Cretaceous to Quaternary. Our study focus on segment of these faults particularly J. Orbat, J. J. Ben Younes, J. Es Stah, J. Attig and Bou Ramli. The kinematics of these faults control distribute of stratigraphic series from Trias Until actual. During Cretaceous an extensive tectonics phase is distinguished particularly of Aptian and Albian period observed by normal faults and half-Graben. During this period the Gafsa basin shows a less sedimentary activity compared to north and south part what explain a less subsidence zone. This extensive mode is confirmed also during Cenomano-Turronian period verified by reduction of series from NW to SE of J. Ben Younes.

During Cenozoic period Gafsa basin show an important thickening of series particularly of Eocene age (Although we notes lacuna of Eocene series in the two sides of Gafsa basin, north and south).

The index of compressive phase is observed by the reactivation of old normal fault to thrust and strike-slip fault. But the important question why we can notes in the same zone the coexistence of thrust faults and strike-slip one knowing that the shortening axis is oblique to front 
of Gafsa and if the base is integrate in the deformation.

Consequently the obliquity of shortening axis to preexistent fault confirms the choice of partitioning model during deformation proved by the coexistence of thrust and strike-slip faults.

\section{Relation Base and Cover}

Many studies in the North African plaque interested to synsedimentary tectonics activity of Triassic series (particularly in its occidental extremity) [22-24]. This activity shows the reactivation of prexisting faults and demonstrate the integration maghrebide basement in the deformation.

In the Gafsa basin the tectonics analysis proposed by [25] shows a structurale discontinuity in the surface controlled by basement activity. [26] considered that the faults corridor in Gafsa basin are controlled by the basement activity and necessary there is a basement deformation and other of cover.

In studied sector the synsedimentary faults are obseved particularly in te Aptian-Albian series in the south of Kroumet Zerga associated (core of structure) to an extensives whetestones that confirme not only the extensive activity manifested in Gafsa basin during Cretaceous but also the fractionation of post triassic cover. Particularly in this zone the triassic blades align according to the orientation of major faults of NW-SE direction and parallel to folds of J. Ben Younes, J. Attig, and J. Bou Ramli (Figure 3).

In this study we supposed that Gafsa basin subjected to a rigorous cover fracturation post triassic. The triassic rising is carried out in the opened fracture during cover extensive. This rising is facilited by halokinematics and rheology of triassic series; indeed the weight of Jurassic and Cretaceous series cause an overload on triassic series of weak density. That consequence of this outcroping of triassic blades marking out the old normal faults. The basement series permeated only a passive decollement but the important deformation is observed in the cover structures.

\section{Folding and Decolment of Cover}

The strain in southern atlassic Tunisia expresses by the folding and decolment of sedimentary cover (Figure 4). The decolment uses various levels of the lithostratigraphic column. The major level in Gafsa basin is situated at the level of Triassic facies [4,6,26-28] .

The geometry of the various structures connected to the thrusting is guided by the extrusion of triassic facies limited by systems of faults of NW-SE of direction (Figure 5).

\section{Relation between Thrusting and Strike Slip Faults}

The thrustings on the surface of NW-SE direction in Gafsa basin affect the southern flank of Ben Younes monocline, in east of Bou Ramli and in southern of Orbat anticline (Figures 6 and 7). According to our study of seismic reflexion, the major thrustings affect the cover with a high dip suggesting that they are old normal faults formed at the time of the opening of Néotéthys at the beginning of Mésozoïque and reversed in the collision during compressive phases. An older heritage is evoked and gives rise to strike slip faults associated to the major thrustings (Figure 8).

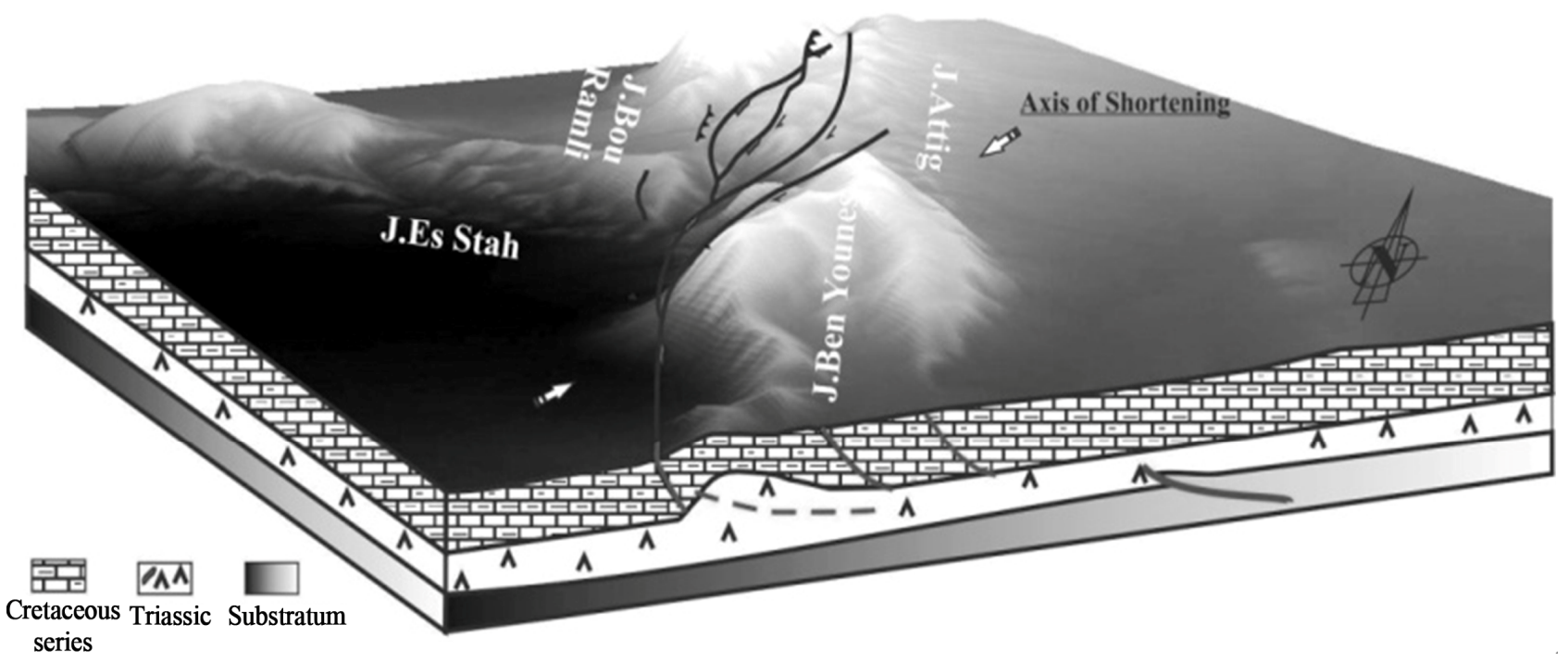

Figure 3. Block diagram in Gafsa basin shows the relation between cover and basement, the role of the faults of the basement in the transport of strain according to a decolment level within Triassic facies. 


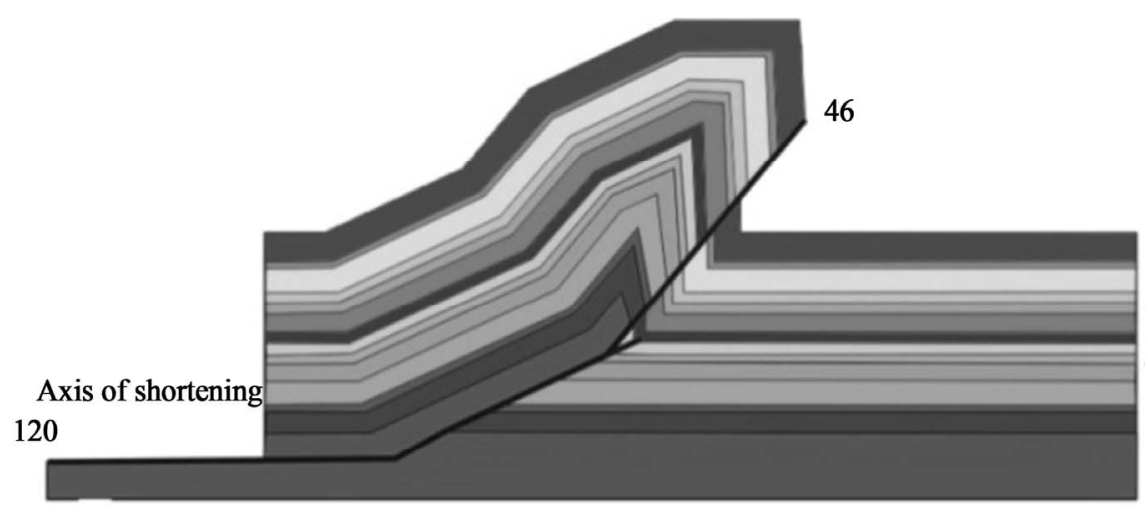

100 pixels

Figure 4. Cross section balanced with the software "Rampe 1.3.2".
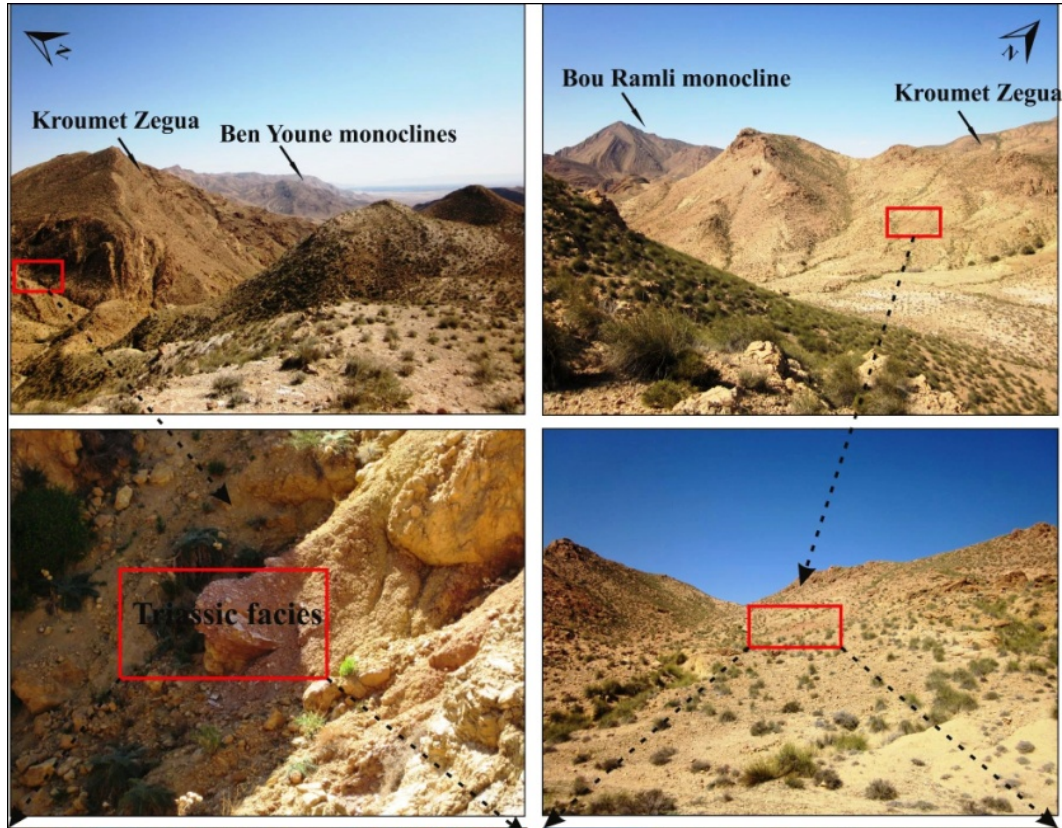

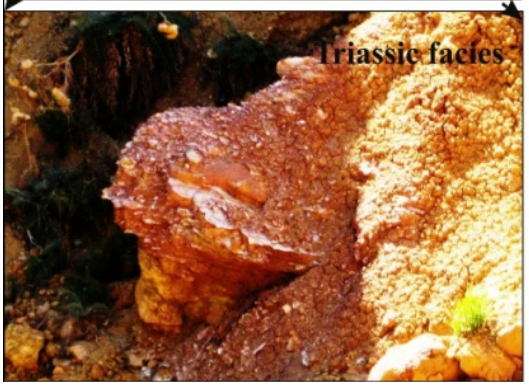

(a)

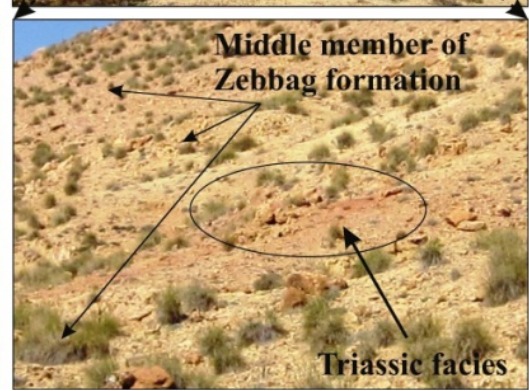

(b)

Figure 5. Representation of Triassic facies in east of Bou Ramli monocline.

The thrusting fault is a discontinuity of basement which disturbs the axis of shortening on the scale of the southern atlassic tunisa since in the basin of Gafsa,

The transpressive strain was adapted by various structures like folds and thrusting of variable direction and a major fault of NW-SE direction with opposite movement whereas the strike slip faults as a result of rotation of axis of shortening. These faults are represented by the variations of facies and thicknesses

The thrusting fault in study area is the results of reactivation of preexistant fault of basement which accommodates the mouvement of African and European plates. 

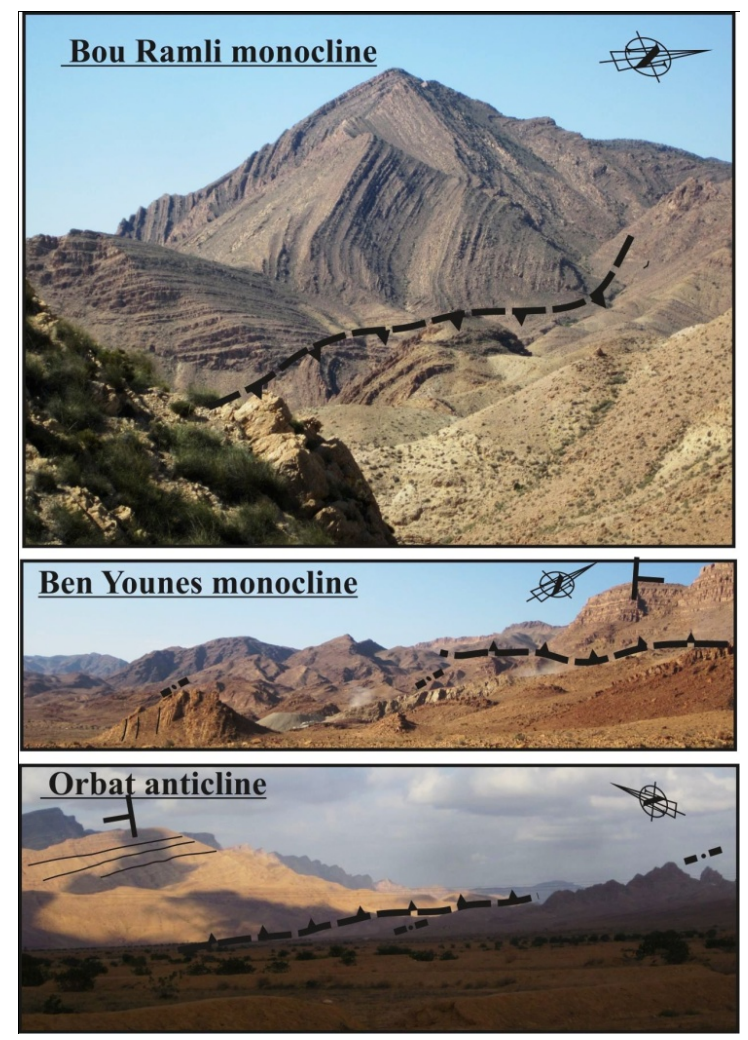

Figure 6. Major thrustings affect Gafsa basin in east of Bou Ramli monocline, in southern of Ben Younes monocline and in southern of Orbat anticline.
The increase of strain is absorbed by the compressives structures which are oblique with axis of shortening of $\mathrm{N}-\mathrm{S}$ direction.

The initiation of the collision, the chains of Tunisia subjected to an oblique convergence between the African Plate and the Eurasia Plate. A tectonic and geomorphological analysis on the major faults of the southern atlassic Tunisia makes it possible to propose a kinematic model in which these faults contribute to the partitioning of the deformation. The tectonic analysis of main faults in southern atlassic Tunisia can proposed the kinematic model of strain partitioning under control of oblique ramp.

\section{Modeling and Discussion}

During approaching of two blocs, the deformation can be absorbed along the largest orogenic domain. The distribution of deformation in this domain isn't homogeny. It is accommodate by the orientation of different structures (Faults and folds).

Related to the importance of obliquity angle of convergence vector to faults trends, the deformation will be accommodate by partitioning producing a tranpressional deformation [29,30].

The transpressional deformation is accommodating also by the coexistence of strike-slip faults and thrust fault [31,32] It permeated also the genesis of folds in

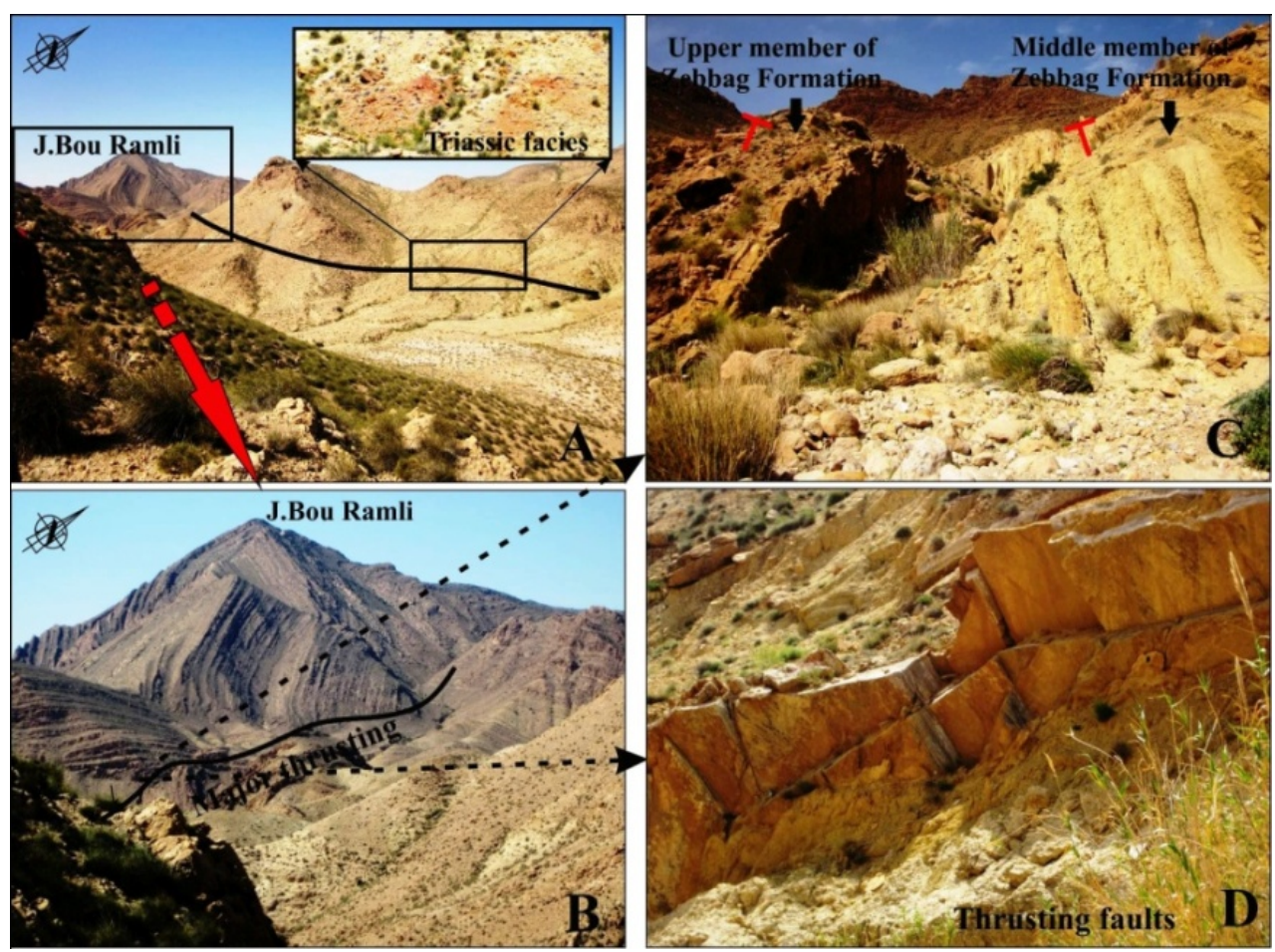

Figure 7. (A) Triassic facies in middle member of Zebbag formation associated with major acident of NW-SE direction; (B) Panoramic viewshows the major thrusting with the various of dipping; (C) Major thrusting in Zebbag formation; (D) Presentation of thrusting faults in east of Bou Ramli monocline. 


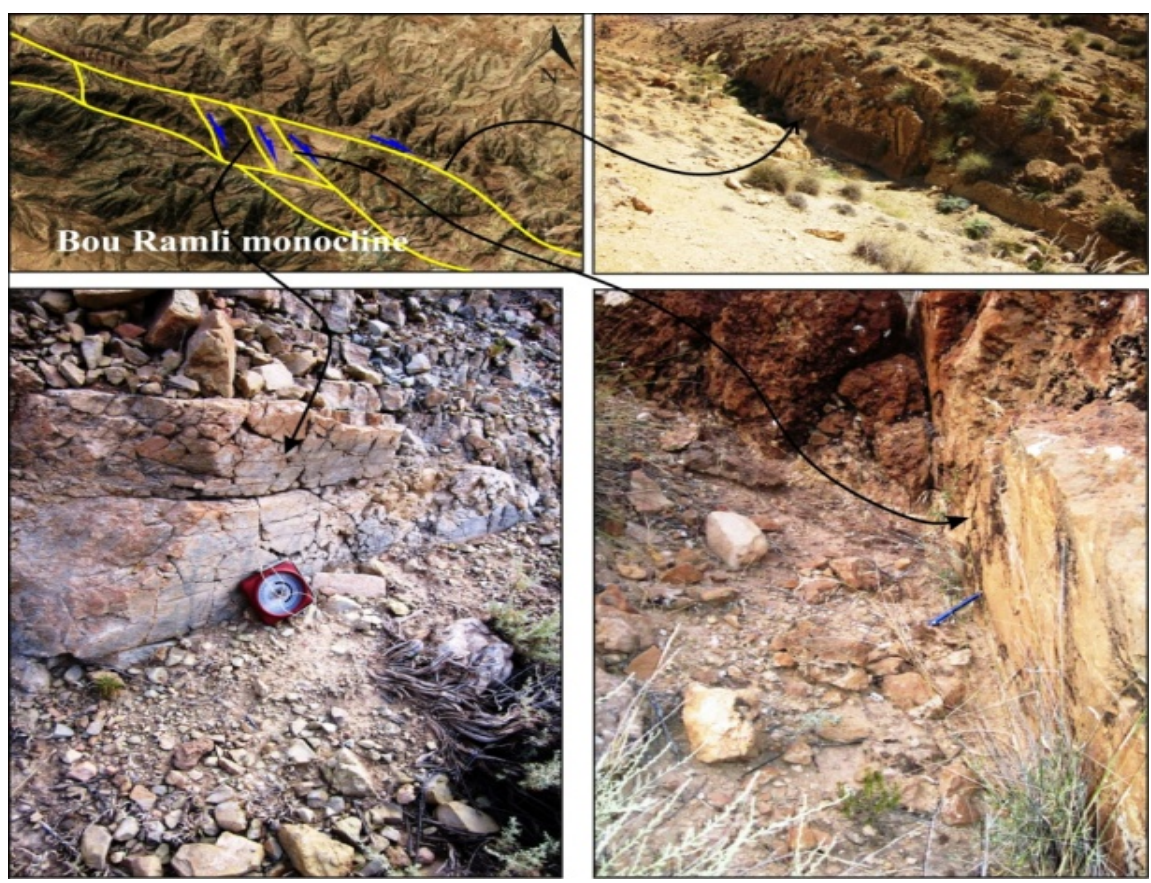

Figure 8. Presentation of major strike slip faults in northern of Bou Ramli monocline.

echelon disposition [12-33].

In Gafsa basin, the massives of Ben younes, Attig and Bou ramli are defined by $\mathrm{N} 115-130$ perpendicular to direction of atlassic folds in central of Tunisia. This particular disposition is related to activity of corridor fault of NW-SE direction (N120).

The oblique position of préexistant fault to shrortening axis permits the genesis of transpressional structures, Gafsa basin characterized by the abundance of transpressional structures associated with major thrusting and strike slip faults, the style of deformation related with the direction of faults that control the genesis of folds. This style of deformation controls the genesis of folds and shows a thrusting associated to dextral and sinistral strike-slip faults (Figure 9). This geometry is verified by the model of partitioning deformation.

\section{Synthesis}

The originality of this work is the interpretation in the first time in North Africa a model of partitioning deformation basing on surface data. This interpretation is related to reactivation of directional preexisting faults during compressive phases.

Many parameters explain the choice of this model particularly the obliquity direction of shortening axis and convergence of field stress during compressive phase. In ground this kinematics is proven by the coexistence of strike-slip and trust faults.

The main problem is the evolution of shortening axis during compressive phase; indeed the study of actual disposition of folds (NW-SE). The direction of stress field is change while approaching to old fault. It is important to signal that the basement faults is not integrate in the deformation but it is the principal conduct on the deviation of stress field. The role of basement structures is a simple displacement of deformation according to decollement level in Triassic series. The maximum of deformation is observed in the forelimb in the cover structures limited by the front of Gafsa. The elevated deformation is observed by the geometries of folds (acute hinge and successful anticline and lacuna of syncline) and the outcropped of Triassic series in the limits of south atlassic front in Gafsa basin.

The examination of the slickensides of faults in the study area shows different generations of striate which shows thrusting associated a strike slip faults. The coexistence of these two types of the faults confirms the model of strain partitioning; particularly the thrusting is the principal accidents of deformation in Gafsa basin. Against the other studies shows that thrust is the results of transpressive activity of Gafsa strike slip faults.

Many model proposed have to explain the transpressional tectonics between African and European plaques, these models require several mechanisms according to variable scale. In intracratonic chains of Gafsa basin, basing on kinematics of faults (coexistence of thrust and strike-slip faults) and the obliquity angle between shortening axis and directional faults, we confirms the application of partitioning deformation responsible to genesis of folds. This model is verified in cover structures without integration of basement structures in deformation 


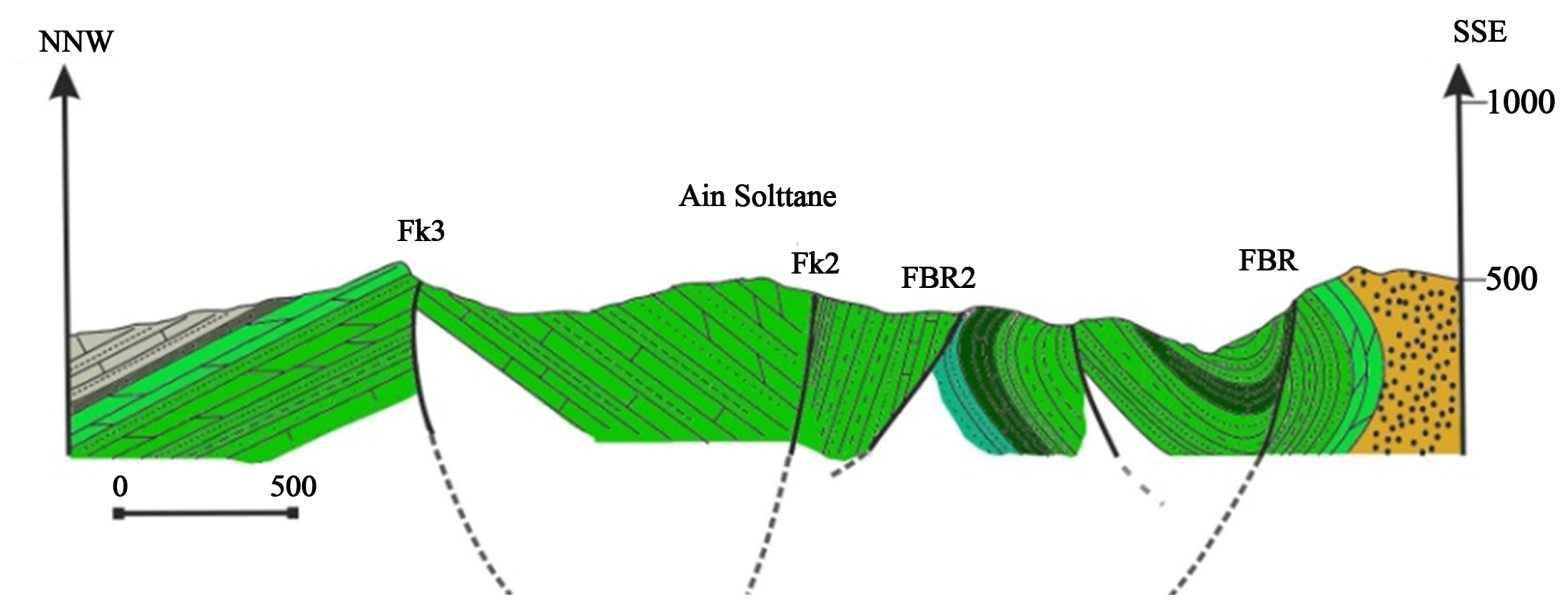

Legendes
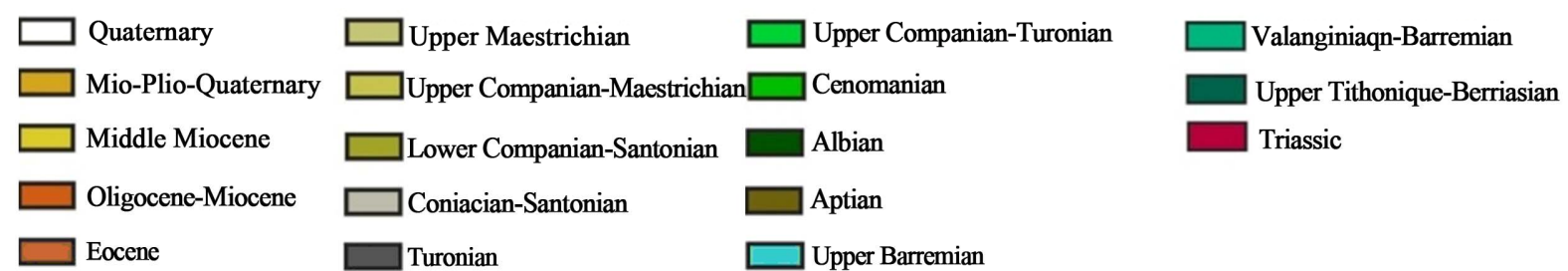

Figure 9. Cross section in east of Bou Ramli monocline shows the relation between major thrusting (FBR2, FBR $\left.{ }^{\circ}\right)$ and the strike slip faults.

associated to decollement level in the top of Triassic series.

\section{REFERENCES}

[1] J. M. Nocquet, "Mesure de la Déformation Crustale en Europe Occidentale par Géodésie Spatiale,” Ph.D. Thesis, University of Nice Sophia Antipolis, Nice, 2002, 307 p.

[2] C. Faccenna, F. Funiciello, D. Giardini and P. Lucente, "Episodic Back-Arc Extension during Restricted Mantle Convection in the Central Mediterranean," Earth and Planetary Science Letters, Vol. 187, No. 1-2, 2001, pp. 105-116. doi:10.1016/S0012-821X(01)00280-1

[3] G. Creuzot, E. Mercier, J. Ouali and P. Tricard, "La Tectogenèse Atlasique en Tunisie Centrale: Apport de la Modélisation Geométrique,” Eclogae Geologicae Helvetiae, Vol. 86, No. 2, 1993, pp. 609-627.

[4] F. Outtani, B. Addoum, E. Mercier, D. F. de Lamotte and J. Andrieux, "Geometry and Kinematics of the South Atlas Front, Algeria and Tunisia,” Tectonophysics, Vol. 249, No. 3-4, 1995, pp. 233-248.

[5] F. Outtani, "Cinématique, Modélisation et Bilan Energétique des Plis de Rampes. Approche Théorique et Application à Deux Régions du Fronts Sud Atlasique,” Thèse de 3ème Cycle, University of Cergy-Pontoise, Pôle Sciences et Techniques-France, 1996, $244 \mathrm{p}$.

[6] R. Ahmadi, J. Ouali, E. Mercier, J. L. Mansy, B. VanVliet Lanoë,. P. Launeau, F. Rhekhiss and S. Rafini, "The Geomorphologic Imprints of Hinge Migration in the Fault-Related Folds. A Case Study in Southern Tunisian Atlas,” Journal of Structural Geology, Vol. 28, No. 4,
2006, pp. 721-728. doi:10.1016/j.jsg.2006.01.004

[7] M. S. Bensalem, M. Ghanmi and F. Zargouni, "Modeling Genesis of Intracratonic Chains Related to Tectonics Inheritance Case Study from Gafsa Basin (Southern Central Tunisia)," Journal of Geography and Geology, Vol. 1, No. 2, 2009, pp. 58-70.

[8] R. McCaffrey, "Oblique Plate Convergence, Slip Vectors, and Forearc Deformation," Journal of Geophysical Research, Vol. 97, No. B6, 1992, pp. 8905-8915. doi:10.1029/92JB00483

[9] P. Molnar, "Brace-Goetze Strength Profiles, the Partitioning of Strike-Slip and Thrust Faulting at Zones of Oblique Convergence, and Stress-Heat Flow Paradox of the San Andreas Fault,” In: B. Evans and T.-F. Wong, Eds., Fault Mechanics and Transport Properties of Rocks, Academic Press, London, 1992, pp. 435-459.

[10] R. R. Jones and P. W. G. Tanner, "Strain Partitioning in Transpression Zones,” Journal of Structural Geology, Vol. 17, No. 6, 1995, pp. 793-802. doi:10.1016/0191-8141(94)00102-6

[11] J. C. Hu, J. Angelier, C. Homberg, J. C. Lee and H. T. Chu, "Three-Dimensional Modeling of the Behavior of the Oblique Convergence Boundary of Southeast Taiwan: Friction and Strain Partitioning," Tectonophysics, Vol. 333, No. 1-2, 2001, pp. 261-276. doi:10.1016/S0040-1951(00)00278-X

[12] P. Richard and P. R. Cobbold, "Experimental Insights into Partitioning of Fault Motions in Continental Convergent Wrench Zones,” Annales Tectonicae, Vol. 4, 1990, pp. 35-44.

[13] J. S. Oldowet, A. W. Bally and H. G. Avé Lallemant, 
"Transpression, Orogenic Float, and Lithospheric Balance,” Geological Society of America, Vol. 18, No. 10, 1990.

[14] G. Scalera, "A New Interpretation of the Mediterranean Arcs: Mantle Wedge Intrusion Instead of Subduction," Bollettino della Società Geologica Italiana, No. S5, 2005.

[15] Y. Missenard, "Crustal versus Asthenospheric Origin of the Relief of the Atlas Mountains of Marocco," Journal of Geophysical Research, Vol. 111, No. B3, 2006, Article ID: B03401. doi:10.1029/2005JB003708

[16] E. Laville, A. Charroud, B. Fedan, M. Charroud and A. Piqué, "Inversion Negative et Rifting Atlasique: Exemple du Basin Triasique de Kerrouchène,” Bulletin de la Société Géologique de France, Vol. 166, 1995, pp. 364374.

[17] E. Laville, A. Piqué, M. Amrhar and M. Charroud, "A Restatement of the Mesozoic Atlasic Rifting (Marocco),” Journal of African Earth Sciences, Vol. 38, No. 2, 2004, pp. 145-153. doi:10.1016/j.jafrearsci.2003.12.003

[18] P. F. Burollet, “Contribution à L'étude Stratigraphique de la Tunisie Centrale,” Annales des Mines et de la Geologie, La Rapide, Tunis, Vol. 18, 1956, 350 p.

[19] J. Dercourt, L. E. Ricou and B. Vrielinck, “Atlas Thethys of Paleoenvironmental Maps,” Gauthier-Villars, Paris, 1993.

[20] G. Rosenbaum, S. L. R. Gordon and C. Duboz, "Relative Motions of Africa, Iberia and Europe during Alpine Orogeny," Tectonophysics, Vol. 359, No. 1-2, 2002, pp. 117129. doi:10.1016/S0040-1951(02)00442-0

[21] D. F. de Lamotte, B. Saint Bézar, R. Bracène and E. Mercier, "The Two Main Steps of the Atlas Building and Geodynamics of the Western Mediterranean,” Tectonics, Vol. 19, No. 4, 2000, pp. 740-761. doi:10.1029/2000TC900003

[22] B. Biju-Duvabl, "Les Bassins de la Méditerranée Orientale Reposent-ils sur les Restes D'un Domaine Océanique, la Mésogée, Ouvert au Mésozoïque et Distinct de la Téthys?” Bulletin de la Societe Géologique de France, No. 7, 1980.

[23] J. L. Laville, "Lesage Géométrie, Cinématique Dynamique de la Tectonique Atlasique sur le Versant Sud du Haut Atlas Marocain. Apercu sur les Tectoniques Hercyniennes et Tardi-Hercyniennes," Bulletin de la Société Géologique de France, Vol. 19, No. 7, 1977, pp. 527-539.
[24] C. Soyer, "Inversions Structurales le Long de la Direction Atlasique en Tunisie Centrale; le Jebel Boudinar,” Thèse University de Grenoble, 1987.

[25] F. Zargouni, “Tectonique de L’Atlas Méridional de la Tunisie, Evolution Géométrique et Cinématique des Structures en Zone de Cisaillement,” Ph.D. Thesis University, Louis Pasteur de Strasbourg et Revue des Sciences de la Terre de LINRST, Vol. 304, 1985.

[26] H. Amor, "Etude Geophysique et Geologique des Bassins et des Chaines de Tunisie Centrale et Méridionale Durant le Mézosoique et le Cenozoique,” Thèse de Doctorat, Université Pierre et Marie Curie, Paris, 1998.

[27] M. S. Bensalem, "Etude des Chaines Orogéniques dans les Zones Externes: Exemple L'atlas Centro-Méridional. Apport des Données de Surface et de Subsurface,” Thèse de Doctorat, Faculté des Sciences de Tunis El Manar, 2010.

[28] S. Amamria, M. S. Bensalem, M. Ghanmi and F. Zargouni, "Condition of Development of Collapse Structure in the Southern-Central Atlassic Tunisia Case Study to Gafsa Basin,” Arabian Journal of Geosciences, 2010. doi:10.1007/s12517-011-0462-9

[29] R. McCaffrey, "Estimates of Modern Arc-Parallel Strain Rates in Fore Arcs," Geology, Vol. 24, 1996, pp. 27-30. doi:10.1130/0091-7613(1996)024<0027:EOMAPS >2.3.C $\underline{\mathrm{O} ; 2}$

[30] J. Delteil, E. Ruellan, I. Wright and T. Matsumoto, "Structure and Structural Development of the Havre Trough (SW Pacific)," Journal of Geophysical Research, Vol. 107, No. 7, 2002, pp. ETG 7-1-ETG 7-17. doi:10.1029/2001JB000494

[31] R. I. Walcott, "Plate Motion and Shear Strain Rates in Thevicinity of the Southern Alps,” In: R. I. Walcott and M. M. Cresswell, Eds., The Origin of the Southern Alps, 1979, pp. 5-12.

[32] R. J. Norris and A. F. Cooper, "Origin of Small-Scale Segmentation and Transpressional Thrusting along the Alpine Fault," New Zealand Geological Society of America Bulletin, Vol. 107, No. 2, 1995, pp. 231-240.

[33] B. Tikoff and K. Peterson, "Physical Experiments of Transpressional Folding,” Journal of Structural Geology, Vol. 20, No. 6, 1998, pp. 661-672. doi:10.1016/S0191-8141(98)00004-2 